\title{
IDENTIFICATION, DETENTION AND BODY SEARCH TECHNIQUES OF THE MILITARY POLICE OFFICERS IN OPERATIONS OTHER THEN WAR
}

\section{TECHNIKI IDENTYFIKACJI, ZATRZYMANIA I PRZESZUKAŃ OSOBISTYCH FUNKCJONARIUSZY ŻANDARMERII WOJSKOWEJ W OPERACJACH INNYCH NIŻ WOJNA}

\author{
Krasimir Paskalev ${ }^{1}$ \\ VASIL LEVSKI NATIONAL MILITARY UNIVERSITY, \\ VELIKO TARNOVO
}

\begin{abstract}
The Military police enable commanders by providing a unique set of abilities that sustaining the joint functions and the military functions of the army through the military police disciplines of the police operations, detention operations and the security and mobility support. The purpose of the report is to describe the support and actions of the military police provided to the army related to the identification, body search and detention in the protection of civil society in operations other than war.

Streszczenie: Żandarmeria Wojskowa umożliwia dowódcom poprzez zapewnienie unikalnego zestawu umiejętności, które podtrzymują wspólne funkcje i funkcje wojskowe armii poprzez wojskowe dyscypliny policyjne operacji policyjnych, operacji zatrzymania oraz bezpieczeństwa i wsparcia w zakresie mobilności. Celem raportu jest opisanie wsparcia i działań żandarmerii wojskowej na rzecz armii w zakresie identyfikacji, przeszukiwania ciała i przetrzymywania w celu ochrony społeczeństwa obywatelskiego w operacjach innych niż wojna.
\end{abstract}

Keywords: military police, detention, search, techniques.

Słowa kluczowe: żandarmeria wojskowa, zatrzymanie, przeszukanie, techniki.

1 Sergeant Krassimir Pavlov Paskalev - fourth year cadet of Vasil Levski National Military University, Veliko Tarnovo, specialty: military police and national and regional security; e-mail: paskalev12345@abv.bg.

Sierżant Krassimir Pavlov Paskalev - podchorąży czwartego roku Uniwersytetu Militarnego im. Vasila Levskiego, Veliko Tarnovo, specjalność: policja militarna, narodowa i regionalne bezpieczeństwo. 


\section{Introduction}

The providing of the civil society protection in operations other than war includes activities which aim to maintain the necessary level of combat potential by increasing and maintaining their ability to ensure the implementation of their tasks. It includes all activities related to the arrest, search and detention of individuals by the Military Police officers.

The subject of this report is the military-police activity on operations other than war. The techniques for identifying, searching and arresting of individuals are the object of the research. The purpose of the report is to reveal the characteristics of the role of officers and units of the Military Police Service in operations other than war.

In order to achieve the main goal, the following tasks are formulated:

1. The techniques for facial recognition will be analyzed.

2. The procedures for body searching of individuals will be considered and analyzed.

3. The procedures for arresting individuals will be analyzed.

The methodology of the research includes the methods of analysis and synthesis, comparison, generalization and formulation of some general conclusions. [3]

\section{Techniques for facial recognition}

The ability to precisely describe the suspect has a significant effect on the success of the search and detention operation allowing the officers to arrest the suspect who may be trying to escape from the group that initially saw him. There are models for describing people - age, build, clothing, distinguishing marks, height (growth), face, gait, hair, gender.

When we try to specify the age of the wanted person, we scrutinize two groups of factors that should to be taken into account - external and internal. The external factors include: the clothing, the environment, entertainments, age of the surrounding persons. The internal factors include the physical marks: complexion, face hair, hair color, wrinkles, acne, body posture, etc.

The most reliable method of establishing age is to group it. The evaluation of what you think about the age in that case is grouped by adding of the one hand or subtracting of the other hand for two years that is why you are giving an age between $18-22$ years if the suspect's age is set to be 20 years. [3]

The description of the build includes a description of the size and shape of the torso and should include: shoulders, chest, abdomen. Only simple words should be used to describe what is seen, such as: thin, fat, with athletic body, strong, thickset and so on. Words such as medium or moderate are not used. The chest may be described as a dove or a barrel for men, or full or flat for women. Jargon words 
such as skinny bitch or fat bastard are not used as it would be uncomfortable if it is necessary to explain the colorful use of perception in the court. [4]

The clothing is not trustworthy, identifying, distinguishing mark because it can be easily changed. Only what is visible such as dark or light colors of clothing, any distinctive marks or distinctive signs, the type of clothing, if it was positively defined, should be reported.

Types of distinguishing marks - tattoos, scars, deformities, moles. By reporting of the distinguishing marks the report should be in the following order - type, location, size, color, shape, design.

As by the establishing of age the grouping of the growth should be given such as 1,70-1,75 m. Usually known measures can be used to determine the height of the suspects (house doors, known objects with similar height).

Face - the appearance can be easily altered by the use of disguise, beard and mustache growth or even by gaining or losing kilograms. However, some of the distinctive features may stand out like for example - shape, eyebrows, mouth, chin, nose, ears, forehead, facial hair. [5]

Gait - The way of the individual walks is an important distinguishing feature especially at night using night vision devices. The main characteristics of the gait include - step length, speed of movement, posture, slouching, upright, way of standing. The ways of describing the gait are: vigorous, hurried, measured, indecisive, clumsy, dragging the feet, limping, etc.

By describing of the hair - color, thickness, quality, cropped or with hairstyle.

By describing of the gender we use - unknown, male or female.

\section{Body search}

The body search techniques are applied by entering in buildings with access control, at a security checkpoint, after an incident, when there are grounds to suspect that in the person there are stolen or forbidden articles, when the person is being held as a precautionary measure.

It should be taken under enormous attention when a body search is performed due to the risk of doubtful brutality, assault or unethical attitude.

Categories of body search - quick body search and detailed body search.

The quick body search is usually performed when working with a large number of people and the detailed body search is not recommended; as preliminary measures to the detailed body search when is it absolutely essential to keep any item of proof.

The detailed body search is usually performed when there are legal motives for suspicion that the subject is in possession of illegal items; when a high degree of confidence is required that the subject does not have illegal items. 
The body search techniques are of key importance for the training of the officers of Military Police Service for the fulfillment of their military-professional tasks. [1]

\section{a. $\quad$ Procedure (Quick Body Search)}

The searching officers should working in pairs as the one of them perform the body search and the other covering and watching him. The searching officers should not stand directly in front or behind the subject to avoid being kicked or butted with the head according to the established procedure. The searcher should not be distracted or intimidated and should avoid eye contact with the subject. The observer should watch for non-verbal communications, such as increased nervousness or tension. When the situation requires the use of weapons the searching officer should avoid crossing the line of fire of the covering officer. Theoretically the person should stand with legs slightly apart and arms extended horizontal sideways. The body search should be made systematically from head to foot. The searching officer should never tap the subject, but use a stroking squeezing movement and thus feel for foreign objects. Any baggage or removed clothing attributable to the subject must also be searched. Such items should be treated with respect. [2]

\section{b. $\quad$ Procedure (Detailed Body Search)}

A detailed body search should be conducted using the same procedure as for the quick body search but with the addition of the following points:

- Establish the identity of the subject and the ownership of baggage and other articles.

- Theoretically the search should be conducted out of the public eye. The detail of the search depends on the suspicion attached and the time available.

- Invite the subject to empty all pockets and remove all items and papers being carried.

- If it is necessary to remove clothing, the subject may do it voluntarily (this fact should be recorded) or the existing competences to require the removal of certain items in or out of the public eye.

- In conducting the search pay attention to every detail particularly: clothing seams, waist bands, belts, collars, lapels, padding, cuffs and turn ups. Socks and shoes provide easily missed hiding places.

- Unless there is some future interview advantage in doing so, no emotion should be shown upon finding articles and significant articles should not be set aside from others. All items should be saved out of reach of the subject. [4] 


\section{c. Coercive actions}

The following are the principal coercive actions with regard to the body search of persons:

The search, in ideal circumstances, is conducted by a person of the same sex as the person to be searched. Some theatres may require that the search of a child under 14 years of age only be conducted by a female.

Generally, there is no authority to require a person to remove clothing in public other than an outer coat, jacket or gloves. Out of the public eye and if not voluntarily done there may be appropriate authority to require the removal of other outer clothing. [5]

\section{d. Records and Reports}

For all categories of search apart from initial searches a record should be maintained. This should contain - details of the person searched, the aim of the search, the grounds for the search, the date and time of the search, the location of the search, details of anything significant found, details of any injury to a person or damage to property, which appears to the searcher to have resulted from the search, establishment of additional data of the searchers.

Every military police officer should fully understand the importance of performing quick and detailed body searches. This could stop the transfer of weapons, ammunition and illegal property from terrorist groups to our societies.

They on their own part knowing the procedures, have their own guesses about changes in the established search practice, so avoid using models that are easy to follow. [5]

\section{Detention}

It is vital for every military officer to know the procedures and to understand fully the laws and the legal ways before to perform a detention. If the arrest procedures are not performed properly in any way, then the military officer who performed the arrest or participated in it can be accused and responsible for the whole number of violations such as assault, theft, racism, illegal arrest. Thus he can be arrested and brought to justice. [5]

\section{a. Arrest procedures - violence and delicacy.}

The authorized use of force by soldiers participating in the peacekeeping operations by body search and arrest of civilians will depend on the mandate and the stature agreement of the soldiers. Things that need to be thought in the most 
peacekeeping operations are violence and delicacy. The rules and regulations on which they are based can be changed. There are various reasons for this such as the country in which they operate may change the mandate for a particular situation or mission. NATO, IFOR, SFOR, the UN may also make changes to the arrest procedures which will be applied to the situation, the mission or to the political climate. It is important for commanders and their soldiers to be familiar with these changes and to be trained to the requirements.

Other difficulties that need to be thought are ethnic divisions, different religions, illegal immigrants, refugees, interned persons. All of these difficulties pose a problem when attempting to identify a person's identity or address. Most of these examples will not be identical. It should be also remembered that the country or organization in which they operate may have modified or different procedures when arresting women or children. [8]

\section{b. General powers of arrest}

During on duty a member of the public security may arrest anyone (aged over 10 years), who is reported to be a suspected of committing or having committed a crime. Although the members of the public security have the power to arrest anyone for a crime, their focus should be on:

- Terrorist type crimes (use or possession of illegal weapons, ammunition, etc.)

- Serious or ordinary criminal offenses (theft, violation of public order, assault, burglary, etc.)

- Sufficient evidence that the person is a member of a revealed terrorist group (refusal to give name, resistance to body search, etc.).

The Guardians may arrest before, during or after the crime, but in any case a voice command should be used. Under normal circumstances in operations other than war it must be working together with a policeman accompanying the patrol, but there are also cases where it can be acting without him. Some arrested should be handed over to the police as soon as possible. [8]

The communication in case of arrest requires that the military officer says: "Military police! You are arrested!". It may be useful to inform his (her) relatives etc. about the causes and circumstances of the arrest. All arrested are accompanied by the military officer who has arrested them. He must be familiar of all the escort requirements to the arrest.

The Women may be arrested on the same suspicions as the men. However, they cannot be searched by men and cannot be left alone with one soldier. These precautions are taken to avoid a statement before the court for a committed attack.

Children under 10 years of age cannot be arrested. Children between 10-17 years of age can be arrested as adults but should be kept separate. The parents and guardians should be notified of the arrest as soon as possible. [5] 
When performing an arrest is to act with discretion, if possible public places with media and television channels are to avoid. The military officer must be firm and polite. Physical force can only be applied when the arrest cannot be performed without it. Do not argue with the suspect. [3]

It is not allowed to talk to the prisoner. Everything he says must be recorded using a Dictaphone. This might be useful evidence against him. To prevent the escape of the arrested the soldier who arrested him should be sent to escort him. Prisoners should not be threatened in any way. The time of the arrest should be recorded and an arrest report should be made. If the arrested person is a terrorist captured with explosives, weapons and ammunition, etc. the evidence should be kept through using the evidence preservation kit and the place of the crime shall be guarded until the arrival of an investigating military policeman and specialists from other structures and agencies. [4]

The arrest report contains detailed information about name, age, religion, address, arrested for, arrest time, place of arrest, name, title and unit of the person who performed the arrest, name, title and unit of the witnesses, subsequent actions - released, delivered to the police. [4]

\section{Use of weapons}

The order of use of weapons, physical force and assistive devices shall be determined by a regulation of the Minister of Defense.

\section{a. Use of weapons}

The Military Police authorities may use weapons only when it is absolutely necessary in armed attacks or threat of fire, by release of hostages and kidnapped persons, after warning in the event arrest of a person who committing or has committed an ordinary violent crime, it the person resists or tries to escape, after a warning to prevent escape of a person, detained accordingly for commission of an ordinary violent crime.

By the use of weapons the authorities must do everything in their power to preserve the life of the person against whom the weapon is directed and not to endanger the live and health of others, including of the authorities that use it.

The authorities may use weapons without warning in armed attacks against them and against persons who is offering armed resistance. Authorities shall suspend the use weapons immediately after the achieving of the legitimate aim.

It is prohibited to use a weapon to detain or prevent the escape of a person who performs or has performed a non-violent act if the person does not pose a risk to the life and health of another. After the use of weapon, the authorities of the Military Police shall prepare a report. [1] 


\section{b. Use of physical force and auxiliary means}

For fulfilling their obligations on duty, the bodies of the Military Police may use physical force and auxiliary means only when it is absolutely necessary by counteraction or refusal to fulfill a legal instruction; detention of a lawbreaker who fails to obey or offers resistance to a police organ; convoying a person or if the latter tries to escape, to commit suicide or murder, or to infringe somebody else's health; rendering assistance to other public authorities or officials who are illegally prevented from fulfilling their obligations; attacks against citizens and police organs; liberation of hostages; group violations of the public order; attacks against buildings, premises, installations and transport means of the Ministry of Defense, the structures of the direct subordination of the Minister of Defense and the Bulgarian Army; freeing of illegally occupied objects of the Ministry of Defense, the structures of the direct subordination of the Minister of Defense and the Bulgarian Army, if they got such instruction by a competent organ. [4]

For fulfilling their obligations on duty, relating to the transfer of classified information, the bodies of the Military Police may use physical force and auxiliary means in the event of unauthorized access to the correspondence only if absolutely necessary. Auxiliary means shall be as follows: handcuffs, strait jackets, batons and devices, chemical substances approved by the Minister of Health, animals on duty, such as dogs, blank cartridges, cartridges with rubber, plastic or shock bullets, devices for coercive stopping of motor vehicles, devices for opening of premises, light or sound devices having a diverting effect, armored machines. [3]

Physical force and auxiliary means shall be applied only after warning, except for the cases of sudden attack or liberation of hostages. The application of physical force and auxiliary means shall be relevant to the specific situation, the character of violation of the public order and the lawbreaker's identity. The Police authorities shall use only the absolutely necessary force. In applying physical force and auxiliary means the police organs shall be obliged to, if possible, protect the health and take any measure to preserve the life of the relevant persons. The application of physical force and auxiliary means shall stop immediately after the purpose of such measure has been achieved. [2]

The application of physical force and auxiliary means in respect of visibly juvenile persons and pregnant women shall be prohibited. Such prohibition shall not be valid in cases of art. 1, points 2, 3, 5, 6 and 8 of the Law on Military Police if all other means have been exhausted. [7]

The use of life-threatening force in detaining or in preventing the escape of a person committing or who has committed a violent offence, unless the persons is not a threat to the life and health of someone else is forbidden. 


\section{Findings:}

As a result of the analysis and studies performed, the following conclusions can be drawn:

1. The analysis of the contemporary operations other than war reveals that potential persons who can be detained by the Military Police units may be soldiers, civilians - part of the coalition forces, civilians from contractor logistic and private military company, which requires a high level of preparedness and training of officers and units of the Military Police for actions in high-risk operations.

2. The profile of the potential persons who can be detained contains a relatively high theoretical possibility to their resist, which argued with a good experience with firearms, tactical shooting skills, survival skills in high-risk situations gained through their professional experience and experience in the structures to which they belong.

3. The results of the analysis reveal the objective need to meet high requirements and to adopt standards in relation to the professional readiness of the officers from the Military Police units for high-risk operations for the successful performance of tactical detention actions in operations other than war and avoidance of loss of life, damage of a material nature and concomitant losses. [3]

\section{Conclusion}

In conclusion, it should be noted that the presented results may be used for the improvement of the methodological and pedagogical requirements for the professional training of the Military Police officers for the fulfillment of their professional tasks in operations other than war. The Military Police authority is specialized in maintaining order and security in the Ministry of Defense, in the Structures subordinated to the Ministry of Defense and to the Bulgarian army and in ensuring the security of their personnel.

Through their ystem of security measures, the authorities of the Service provide physical, personal and information security for the operations performed by the Bulgarian Army. 


\section{REFERENCES}

[1] Krastev K., Terrorism - new regional approaches to the abstruse threat, International Scientific Conference: „South-East Europe: New Threats to Regional Security”, (Sofia: NBU Publ., 2015), 124-132.

[2] Georgiev D., SANS Annual Report'2015, (Sofia: VI Publ., 2016), 9.

[3] Military Police Act, (Promulgated SG No. 48/24.06.2011., effective 24.06.2011),4.

[4] Law on Defence and Armed Forces of the Republic of Bulgaria (Promulgated SG No. 100/20.12.2011, effective 1.01.2012), 45.

[5] White Paper on Defence and Armed Forces of the Republic of Bulgaria (Sofia: VI Publ., 2010), 13.

[6] Programme for the development of the defence capabilities of the Bulgarian armed forces 2020 (Approved by the Council of Ministers of the Republic of Bulgaria Sofia, September 30, 2015), 6.

[7] Draft Amendments to the CC [Criminal Code] to Provide Adequate Penal Protection Against Terrorism (Mar. 10, 2015) retrieved from: http://www.justice.government.bg/117/7316/ published on 10/3/13, last visited on 9/03/2017).

[8] Criminal Code, STATE GAZETTE [SG], No. 26 (Apr. 2, 1968, in force as of May 1, 1968, as last amended by SG No. 32 (Apr. 27, 2010, in force as of May 28, 2010. 